\title{
Neutrophil-to-lymphocyte ratio, platelet-to-lymphocyte ratio and systemic immune-inflammation index in patients with COVID-19-associated pneumonia
}

\section{Luis del Carpio-Orantes, ${ }^{1 *}$ Sergio García-Méndez² and Sara N. Hernández-Hernández ${ }^{3}$}

${ }^{1}$ Department of Internal Medicine, Zone 71 General Hospital, Instituto Mexicano del Seguro Social, Veracruz; ${ }^{2}$ Department of Teaching and Research, Hospital Regional de Alta Especialidad de Oaxaca, Oaxaca; ${ }^{3}$ Clinical Laboratory, Zone 24 General Hospital, Instituto Mexicano del Seguro Social, Veracruz. Mexico

\begin{abstract}
Introduction: There are hematological parameters that correlate severity and predict mortality mainly in septic and inflammatory states. Objective: To correlate the neutrophil-to-lymphocyte ratio (NLR), platelet-to-lymphocyte ratio (PLR) and systemic immune-inflammation index (SIII) with COVID-19 severity. Method: Descriptive, analytical, retrospective study of patients with COVID-19 pneumonia, in whom NLR, PLR and SIII were analyzed. Results: One-hundred patients were included, 54 men and 46 women, with a mean age of $49.4 \pm 19.3$ years. NLR, PLR and SIII means were $10.7 \pm 10.9,290.1 \pm 229.2$, and 2.6 $\pm 3.4 \times 10^{\circ}$, respectively. In $54 \%$, pneumonia was mild, and in $46 \%$, severe. Regarding hospital outcomes, $75 \%$ were discharged due to improvement and $25 \%$ died. NLR, PLR and SIII means of the patients who died versus the patients who improved were $20.4 \pm 16.9$ versus $7.5 \pm 4.9(p=0.001), 417.1 \pm 379.7$ versus $247.7 \pm 127.4(p=0.038)$ and $4.8 \pm 6.1$ versus $1.9 \pm 1.2 \times 10^{9}(p=0.030)$, respectively. Conclusion: Hematological parameters can be used in patients with COVID-19-associated pneumonia as predictors of severity and prognosis.
\end{abstract}

KEY WORDS: Neutrophil-to-lymphocyte ratio. Platelet-to-lymphocyte ratio. Systemic immune-inflammation index. Pneumonia. COVID-19.

\section{Índices neutrófilo/linfocito, plaqueta/linfocito e inmunidad/inflamación sistémica en pacientes con neumonía por COVID-19}

\section{Resumen}

Introducción: Existen índices hematológicos que correlacionan la severidad y predicen la mortalidad, principalmente en estados sépticos y de inflamación. Objetivo: Correlacionar los índices neutrófilo/linfocito (INL), plaqueta/linfocito (IPL) e inmunidad/inflamación sistémica (IIIS) con la severidad de COVID-19. Método: Estudio descriptivo, analítico y retrospectivo de pacientes con neumonía por COVID-19, en quienes se analizaron INL, IPL e IIIS. Resultados: Se incluyeron 100 pacientes, 54 hombres y 46 mujeres, con una media de $49.4 \pm 19.3$ años. Las medias de INL, IPL e IIIS fueron 10.7 $\pm 10.9,290.1 \pm 229.2$ y $2.6 \pm 3.4 \times 10^{9}$, respectivamente. En $54 \%$, la neumonía fue leve y en $46 \%$, grave. En cuanto a los desenlaces hospitalarios, 75 \% egresó por mejoría y $25 \%$ falleció. Las medias de INL, IPL e IIIS de los pacientes que fallecieron versus las de los pacientes que mejoraron fueron $20.4 \pm 16.9$ versus $7.5 \pm 4.9(p=0.001), 417.1 \pm 379.7$ versus $247.7 \pm 127.4(p=0.038)$ y $4.8 \pm 6.1$ versus $1.9 \pm 1.2 \times 10^{9}(p=0.030)$, respectivamente. Conclusión: Los índices hematológicos en pacientes con neumonía por COVID-19 pueden ser empleados como predictores de severidad y pronóstico.

PALABRAS CLAVE: Índice neutrófilo/linfocito. Índice plaquetas/linfocitos. Índice de inmunidad/inflamación sistémica. Neumonía. COVID-19.

Correspondence:

*Luis del Carpio-Orantes

E-mail: neurona23@ hotmail.com
Gac Med Mex. 2020;156:527-531

Contents available at PubMed

www.gacetamedicademexico.com

0016-3813/C 2020 Academia Nacional de Medicina de México, A.C.. Published by Permanyer. This is an open access article under the CC BY-NC-ND license (http://creativecommons.org/licenses/by-nc-nd/4.0/). 


\section{Introduction}

Currently, neutrophil-to-lymphocyte ratio (NLR, absolute neutrophil count/absolute lymphocyte count), platelet-to-lymphocyte ratio (PLR, platelet count/absolute lymphocyte count) and a third parameter that integrates the former two, systemic immune-inflammation index (SIII, which integrates the three cell types: platelets $\mathrm{x}$ neutrophils/lymphocytes) are used. There are other parameters of less value, such as albumin-to-lymphocyte ratio, which measures the nutritional prognostic index. All of them have been studied in cancer as predictors of inflammation, endothelial dysfunction, cardiovascular risk, mortality, survival and recurrence.

$\mathrm{NLR}$ or Zahorec ratio is the inflammation indicator that has been most widely studied in different clinical settings: various types of cancer, diabetes mellitus, hypertension, coronary syndromes, cerebrovascular disease and pulmonary thromboembolism, among others; however, it has not been shown to be very useful by itself, in addition to the fact that it has been difficult for an exact cuttof value to be established. ${ }^{2-5}$

Similarly, PLR is an inflammation parameter intended to predict the prognosis and severity of acute conditions that has been mainly used in sepsis and in diseases that involve chronic inflammation. ${ }^{3-5}$

SIII is a reflection of the conjugation of the latter two. It was developed due to the need to assess homeostasis between the host inflammatory process and its immune system. It has been used mainly in oncology and in the study of sepsis. ${ }^{6}$

One of the advantages of these parameters is that they use simple elements such as the count of various blood cell lines, which is easily obtained by flow cytometry, in addition to their low cost and reproducibility. The main disadvantage lies in the need to obtain cutoff points, since they tend to vary from one population to another.

A study that was performed based on the NHANES meta-analysis, which included 9,427 subjects, demonstrated cutoff points for NLR according to race: 1.76 for African Americans, 2.08 for Hispanics, and 2.24 for Caucasians. General average was 2.15. ${ }^{7}$

In different inflammatory conditions, NLR (the most widely studied) values $>10$ have been reported in cases of sepsis, $>5$ in oncological pathologies and $>3$ in severe cardiovascular diseases; the results were variable according to the studied process, which applies to the other commented parameters. ${ }^{7,8}$
COVID-19, a disease characterized by mild respiratory symptoms or severe pneumonia, affects young adults, followed by older adults; main risk factors are the presence of heart disease, hypertension or diabetes. Patients with chronic lung disease are usually less affected. However, there are reports of healthy individuals who have died from the disease, without always having predictive elements of severity such as C-reactive protein, procalcitonin, D-dimer and ferritin markers, among others, which is why establishing more accessible markers constitutes a current concern. ${ }^{9}$

In a study conducted in China with 116 patients affected by COVID-19, a NLR of 2.91 (1.87-4.83) and PLR of 169.0 (123.5-245.6) were found. In a subgroup of seriously ill patients ( $n=27$ ), a NLR of 8.71 (3.77-14.44) and PLR of 246.0 (167.9-456.7) were recorded. A more specific subgroup, which included critically ill patients admitted to the intensive care unit, showed a NLR of 14.44 (6.89-27) and PLR of 235.4 (185.1-573.9), which indicates that lymphocyte decrease and NLR increase are the most evident abnormalities related to disease severity and clinical classification. ${ }^{10}$

\section{Method}

Descriptive, analytical, retrospective study of adult patients who were admitted with COVID-19-associated pneumonia between April and May 2020 to Zone 71 General Hospital "Benito Coquet Lagunes", which depends on the North Veracruz Delegation of the Mexican Institute of Social Security. Confirmation was obtained by quantitative RT-PCR for SARS-CoV-2 with the SuperScript ${ }^{\mathrm{TM}}$ III Platinum ${ }^{\mathrm{TM}}$ One Step Quantitative RT-PCR System kit (Invitrogen, Massachusetts, USA), at the National Coordination of Epidemiological Surveillance Central Epidemiology Laboratory. Patient general data and baseline flow cytometry were recorded and NLR, PLR and SIII were calculated. Statistical analysis was carried out with the SPSS program and consisted of a stratified comparison by hospital outcome and correlation of variables.

\section{Results}

One hundred consecutive patients with a confirmed COVID-19 diagnosis were included, 46 (46\%) women and $54(54 \%)$ men, with a mean age of $49.4 \pm 19.3$ years. Mean leukocyte count was 10,103.0 $\pm 4,289.0$ 
Table 1. Variables in 100 patients with COVID-19 confirmed diagnosis

\begin{tabular}{|c|c|}
\hline Variable & Value \\
\hline Age, years (mean $\pm S D)$ & $49.4 \pm 19.3$ \\
\hline $\begin{array}{l}\text { Gender, n (\%) } \\
\text { Females } \\
\text { Males }\end{array}$ & $\begin{array}{l}46(46) \\
54(54)\end{array}$ \\
\hline $\begin{array}{l}\text { Laboratory variables (mean } \pm \text { SD) } \\
\text { Leukocytes, cells } / \mathrm{mm}^{3} \\
\text { Neutrophils, cells } / \mathrm{mm}^{3} \\
\text { Lymphocytes, cells } / \mathrm{mm}^{3} \\
\text { Platelets, cells } / \mathrm{mm}^{3}\end{array}$ & $\begin{array}{c}10,103.0 \pm 4,289.0 \\
8,509.3 \pm 4,216.0 \\
1,112.7 \pm 585.4 \\
258,548.0 \pm 127,947.2\end{array}$ \\
\hline $\begin{array}{l}\text { Hematological severity } \\
\text { parameters (mean } \pm \mathrm{SD} \text { ) } \\
\text { Neutrophil-to-lymphocyte ratio } \\
\text { Platelet-to-lymphocyte ratio } \\
\text { Systemic immune-inflammation index }\end{array}$ & $\begin{array}{c}10.7 \pm 10.9 \\
290.1 \pm 229.2 \\
2.6 \pm 3.4 \times 10^{9}\end{array}$ \\
\hline $\begin{array}{l}\text { Type of COVID-19-associated } \\
\text { pneumonia, n(\%) } \\
\text { Mild pneumonia } \\
\text { Severe pneumonia }\end{array}$ & $\begin{array}{l}54(54) \\
46(46)\end{array}$ \\
\hline $\begin{array}{l}\text { Hospital outcome, n (\%) } \\
\text { Improvement } \\
\text { Death }\end{array}$ & $\begin{array}{l}75(75) \\
25(25)\end{array}$ \\
\hline
\end{tabular}

cells $/ \mathrm{mm}^{3}$, mean neutrophil count was $8,509.3 \pm 4,216.0$ cells $/ \mathrm{mm}^{3}$ and mean lymphocyte count was $1,112.7 \pm$ $585.4 \mathrm{cells} / \mathrm{mm}^{3}$. As for the hematological parameters used to measure severity, mean NLR was $10.7 \pm 10.9$, mean PLR was $290.1 \pm 229.2$, and mean SIII, $2.6 \pm 3.4$ x $10^{9}$ (Table 1).

Regarding the type of pneumonia, 54 (54\%) of patients had mild pneumonia, and 46 (46\%), severe pneumonia. As for hospital outcomes, 75 (75\%) patients were discharged due to clinical improvement and $25(25 \%)$ died during hospital stay (Table 1).

In the comparative analysis of demographic, laboratory and pneumonia-type variables, stratified by hospital outcome (discharge due to improvement or in-hospital death), the results were as follows: mean age was higher in the group of patients who died during hospital stay $(45.9 \pm 18.6$ vs. $60.0 \pm 17.5$ years, $p=$ 0.001 ) and the proportion of women who died was higher, with a tendency towards statistical significance (Table 2).

Regarding laboratory variables, mean leukocyte count was higher in the group of patients who died, but it was not significantly different: 11,629.6 \pm 6,423.6 vs. $9,594.1 \pm 3,190, p=139$. Mean neutrophil count was higher in the group of patients who died and the difference tended to be statistically significant: $10,466.8$ $\pm 6,204.1$ vs. $7,856.8 \pm 3,093.6, p=0.053$. Conversely, mean lymphocyte and platelet counts were lower in the patients who died in comparison with those of the patients who were discharged due to improvement; both differences were statistically significant: $628.8 \pm$ $419.3(p=0.001)$ and $1,274.0 \pm 544.5$, respectively (Table 2).

Mean hematological parameters were higher in the group of patients who died, with the differences being statistically significant. Mean NLR was $20.4 \pm 16.9$ in the patients who died vs. $7.5 \pm 4.9$ in the patients who improved $(p=0.001)$. Mean PLR was $417.1 \pm 379.7$ in the patients who died vs. $247.7 \pm 127.4$ in the patients who improved $(p=0.038)$. Finally, mean SIII was significantly higher in the patients who died vs. that of the patients who improved $(4.8 \pm 6.1$ vs. $1.9 \pm 1.2$, $p=0.030$, respectively).

Regarding the analysis of the correlation between demographic variables, hematological severity parameters and type of pneumonia, as it was to be expected, high and significant r's were found between all three parameters (Table 3), as well as moderate, but significant r's between NLR and the presence of severe pneumonia $(0.523, p=0.001)$, between NLR and death $(0.533, p=0.001)$ and between the type of pneumonia and death $(0.626, p=0.001)$. Finally, we found low, but statistically significant associations between the female gender and death $(0.209, p=0.037)$, between age and death $(0.321, p=0.001)$, and between SIII and severe pneumonia $(0.204, p=0.042)$.

\section{Discussion}

There are only few studies that address hematological parameters in relation to COVID-19, and the aforementioned one that demonstrated the usefulness of NLR and PLR in relation to disease severity is among the most illustrative in this pandemic. ${ }^{10}$ Our results involve a third parameter that integrates the latter two, systemic immunity and inflammation, which has greater weight when exploring both areas of the host and, in case of indicating an imbalance, it may be related to higher disease severity and poor prognosis.

As in previous investigations around the parameters, it was difficult to establish a cutoff value, although it was corroborated that the higher the values are, the more serious disease they are related to, which can be extrapolated to patients with COVID-19-associated pneumonia. Secondarily, other interesting data are observed, 
Table 2. Comparative analysis of studied variables stratified by hospital outcome in 100 patients with COVID-19 confirmed diagnosis

\begin{tabular}{|c|c|c|c|}
\hline Variable & Improvement $(n=75)$ & Death $(n=25)$ & p \\
\hline $\begin{array}{l}\text { Demographic variables } \\
\text { Age, years } \\
\text { Gender, } n(\%) \\
\text { Females } \\
\text { Males }\end{array}$ & $\begin{array}{l}45.9(18.6) \\
30(40.0) \\
45(60.0)\end{array}$ & $\begin{array}{l}60.0(17.5) \\
16(64.0) \\
9(36.0)\end{array}$ & $\begin{array}{l}0.001^{*} \\
0.063^{*} \\
0.063^{*}\end{array}$ \\
\hline $\begin{array}{l}\text { Type of COVID-19-associated pneumonia, n (\%) } \\
\text { Mild pneumonia } \\
\text { Severe pneumonia }\end{array}$ & $\begin{array}{l}54(72.0) \\
21(28.0)\end{array}$ & $\begin{array}{c}0(0.0) \\
25(100.0)\end{array}$ & $\begin{array}{l}0.001^{*} \\
0.001^{*}\end{array}$ \\
\hline $\begin{array}{l}\text { Laboratory variables (mean } \pm \mathrm{SD} \text { ) } \\
\text { Leukocytes, cells } / \mathrm{mm}^{3} \\
\text { Neutrophils, cells } / \mathrm{mm}^{3} \\
\text { Lymphocytes, cells } / \mathrm{mm}^{3} \\
\text { Platelets, cells/mm } / \mathrm{mm}^{3}\end{array}$ & $\begin{array}{c}9,594.1 \pm 3,190.4 \\
7,856.8 \pm 3,093.6 \\
1,274.0 \pm 544.5 \\
275,450.6 \pm 113,072.5\end{array}$ & $\begin{aligned} 11,629.6 & \pm 6,423.6 \\
10,466.8 & \pm 6,204.1 \\
628.8 & \pm 419.3 \\
207,840.0 & \pm 156,637.7\end{aligned}$ & $\begin{array}{l}0.139^{* *} \\
0.053^{* *} \\
0.001^{* *} \\
0.021^{* *}\end{array}$ \\
\hline $\begin{array}{l}\text { Hematological severity parameters (mean } \pm \text { SD) } \\
\text { Neutrophil-to-lymphocyte ratio } \\
\text { Platelet-to-lymphocyte ratio } \\
\text { Systemic immune-inflammation index }\end{array}$ & $\begin{array}{c}7.5 \pm 4.9 \\
247.7 \pm 127.4 \\
1.9 \pm 1.2 \times 10^{9}\end{array}$ & $\begin{array}{c}20.4 \pm 16.9 \\
417.1 \pm 379.7 \\
4.8 \pm 6.1 \times 10^{9}\end{array}$ & $\begin{array}{l}0.001^{\star *} \\
0.038^{\star *} \\
0.030^{\star \star}\end{array}$ \\
\hline
\end{tabular}

*Student's t-test.

${ }^{* *}$ Chi-square with Fisher's exact test.

Table 3. Correlation analysis of hematological severity variables with hospital outcome in 100 patients with COVID-19 confirmed diagnosis

\begin{tabular}{|c|c|c|c|c|c|c|c|}
\hline Variable & Female gender & Age & NLR & PLR & SIII & Serious pneumonia & Death \\
\hline $\begin{array}{l}\text { Gender } \\
r \\
p\end{array}$ & 1.000 & & & & & & \\
\hline $\begin{array}{l}\text { Age } \\
r \\
p\end{array}$ & $\begin{array}{c}0.060^{\S} \\
0.552\end{array}$ & 1.000 & & & & & \\
\hline $\begin{array}{l}\text { Neutrophil-to-lymphocyte ratio } \\
r \\
p\end{array}$ & $\begin{array}{l}0.625^{\S} \\
0.521\end{array}$ & $\begin{array}{c}0.185^{\ddagger} \\
0.660\end{array}$ & 1.000 & & & & \\
\hline $\begin{array}{l}\text { Platelet-to-neutrophil ratio } \\
r \\
p\end{array}$ & $\begin{array}{c}-0.068^{\S} \\
0.501\end{array}$ & $\begin{array}{c}0.030^{ \pm} \\
0.771\end{array}$ & $\begin{array}{l}0.441^{f} \\
0.001\end{array}$ & 1.000 & & & \\
\hline $\begin{array}{l}\text { Systemic immune-inflammation index } \\
r \\
p\end{array}$ & $\begin{array}{c}-0.033^{f} \\
0.742\end{array}$ & $\begin{array}{l}0.097^{£} \\
0.338\end{array}$ & $\begin{array}{l}0.737^{£} \\
0.001\end{array}$ & $\begin{array}{l}0.705^{£} \\
0.001\end{array}$ & 1.000 & & \\
\hline $\begin{array}{l}\text { Severe pneumonia } \\
r \\
p\end{array}$ & $\begin{array}{c}0.155^{\star} \\
0.125\end{array}$ & $\begin{array}{c}0.512^{£} \\
0.001\end{array}$ & $\begin{array}{c}0.523^{f} \\
0.001\end{array}$ & $\begin{array}{c}0.182^{£} \\
0.069\end{array}$ & $\begin{array}{c}0.204^{£} \\
0.042\end{array}$ & 1.000 & \\
\hline $\begin{array}{c}\text { Death } \\
r \\
p\end{array}$ & $\begin{array}{c}0.209^{*} \\
0.037\end{array}$ & $\begin{array}{l}0.321^{\S} \\
0.001\end{array}$ & $\begin{array}{l}0.533^{\S} \\
0.001\end{array}$ & $\begin{array}{c}0.199 \S \\
0.047\end{array}$ & $\begin{array}{c}0.176^{\S} \\
0.079\end{array}$ & $\begin{array}{l}0.626^{\S} \\
0.001\end{array}$ & 1.000 \\
\hline
\end{tabular}

NLR=neutrophil-to-lymphocyte ratio, PLR=platelet-to-lymphocyte ratio, SIII=systemic immune-inflammation index. sSpearman correlation. sPearson correlation. *Phi correlation.

such as higher mortality in females and in older age subjects, as well as the development of severe pneumonia in those with elevated SIII. More research is needed in order to explore the relationship of the analyzed parameters in other populations affected by COVID-19. 


\section{Conclusions}

NLR, PLR and SIII are parameters that can be used as predictors of severity and hospital outcome in patients with COVID-19-associated pneumonia. Secondarily, they can detect a severe inflammatory process and immune system homeostasis loss, which entail severe clinical pictures and poor prognosis.

\section{Conflicts of interest}

The authors declare that they have no conflicts of interest.

\section{Funding}

The authors did not receive any sponsoring to carry out this article.

\section{Ethical disclosures}

Protection of human and animal subjects. The authors declare that no experiments were performed on humans or animals for this research.

Confidentiality of data. The authors declare that they have followed the protocols of their work center on the publication of patient data.
Right to privacy and informed consent. The authors declare that no patient data appear in this article.

\section{References}

1. Lagunas-Alvarado M, Mijangos-Huesca FJ, Terán-González JO, Lagunas-Alvarado MG, Martínez-Zavala N, Reyes-Franco I, et al. Índice de inmunidad-inflamación sistémica en sepsis. Med Int Mex. 2017;33: 303-309

2. Zahorec R. Ratio of neutrophil to lymphocyte counts-rapid and simple parameter of systemic inflammation and stress in critically ill. Bratisl Lek Listy. 2001;102:5-14.

3. Proctor MJ, Morrison DS, Talwar D, Balmer SM, Fletcher CD, Foulis AK, et al. A comparison of inflammation-based prognostic scores in patients with cancer. A Glasgow Inflammation Outcome Study. Eur J Cancer. 2011;47:2633-2641.

4. Hu B, Yang XR, Xu Y, Sun YF, Sun C, Guo W, et al. Systemic immune-inflammation index predicts prognosis of patients after curative resection for hepatocellular carcinoma. Clin Cancer Res. 2014;20:62126222.

5. Gürol G, Çiftci IH, Terizi HA, Atasoy AR, Ozbek A, Köroglu M. Are there standardized cutoff values for neutrophil-lymphocyte ratios in bacteremia or sepsis? J Microbiol Biotechnol. 2015;25:521-525.

6. Furuncuoğlu Y, Tulgar S, Dogan AN, Cakar S, Tulgar YK, Cakiroglu B. How obesity affects the neutrophi//lymphocyte and platelet/lymphocyte ratio, systemic immune-inflammatory index and platelet indices: a retrospective study. Eur Rev Med Pharmacol Sci. 2016;20:13001306.

7. Azab B, Camacho-Rivera M, Taioli E. Average values and racial differences of neutrophil lymphocyte ratio among a nationally representative sample of United States subjects. PLoS One. 2014;9:e112361.

8. Urrejola GI, Bambs CE, Espinoza MA, Gellona J, Zúñiga AM, Molina ME, et al. Un índice neutrófilo/linfocito elevado se asocia a peor pronóstico en cáncer de colon etapa II resecado. Rev Med Chile. 2013;141:602-608.

9. Del Carpio-Orantes L. Del 2019-nCoV al COVID-19, caracterizando la enfermedad. Med Int Mex. 2020;36:414-417.

10. Sun S, Cai X, Wang H, He G, Lin Y, Lu B, et al. Abnormalities of peripheral blood system in patients with COVID-19 in Wenzhou, China. Clin Chim Acta. 2020;507:174-180. 